\title{
DETERMINATION OF DIFFERENCES IN ANATOMICAL AND CHEMICAL CHARACTERISTICS OF TENSION AND OPPOSITE WOOD OF 8-YEAR OLD EUCALYPTUS GLOBULUS
}

\author{
María G. Aguayo ${ }^{1,2}$, Licarayen Quintupill ${ }^{1}$, Rosario Castillo ${ }^{1}$, Jaime Baeza ${ }^{1,3}$, Juanita Freer ${ }^{1,3}$, \\ Regis T. Mendonça ${ }^{1,2}$
}

\begin{abstract}
Tension and opposite wood, divided in the corresponding heartwood and sapwood regions, from 8-year old Eucalyptus globulus trees were characterized for chemical composition and fibre anatomy in the transverse section in order to identify the main differences. Thicker and poorly lignified cell walls were found in tension wood. Cellulose content was similar for both woods, although tension wood contained $30 \%$ higher xylose and $15 \%$ less lignin than opposite wood. Lignin of tension wood contained $24 \%$ more syringyl units and a higher frequency of $\beta-O-4$ linkages. Principal component analysis (PCA) performed separately with anatomical and chemical data showed a clear separation between tension and opposite wood. The principal characteristics used for separation were: cell wall thickness, vessel diameter, lumen diameter, lignin and xylose content, and amount of syringyl units. Keywords: Tension wood, Eucalyptus globulus, carbohydrates, lignin, wood anatomy.
\end{abstract}

\section{RESUMEN}

La madera de tensión y opuesta, dividida en las correspondientes regiones de albura y duramen, de árboles de 8 años de Eucalyptus globulus fueron caracterizadas con respecto a su composición química y anatomía de la fibra (en la sección tranversal) de manera de identificar las principales diferencias. Paredes celulares gruesas y poco lignificadas fueron encontradas en la madera de tensión. El contenido de celulosa fue similar en ambos tipos de madera, sin embargo, la madera de tensión contiene $30 \%$ más xilosa y $15 \%$ menos lignina que la madera opuesta. La lignina de la madera de tensión contiene $24 \%$ más unidades siringilo y una alta frecuencia de enlaces $\beta-O-4$. El análisis de componentes principales (PCA) realizado separadamente para los datos anatómicos y químicos mostró una clara separación entre la madera de tensión y opuesta. Las principales características utilizadas para la separación fueron el espesor de pared celular, diámetro de vasos, diámetro de lumen, contenidos de lignina y xilosa, y contenido de unidades siringilo.

Palabras clave: Madera de tensión, Eucalyptus globulus, carbohidratos, lignina, anatomía de la madera.

\section{INTRODUCTION}

During tree growth hardwoods can initiate the formation of tension wood, which is strongly stressed wood on the upper side of the stem and branches. The main factors responsible for the formation of this type of wood are: soil subsidence, heavy loads, winds and any other gravitational stimulus that affect the natural trend of a tree's vertical growth (Bamber 2001). The cellulose microfibrils in tension wood act like stretched longitudinal springs that pull the leaning stem upright to its normal position (Bamber 2001; Clair et al. 2006). Even though tension wood is most often associated with leaning or bent trees it has also been reported in well grown, straight, vertical stems of several species including Eucalyptus (Wahyudi et al. 1999, 2000; Washusen and Ilic 2001; Washusen 2002).

\footnotetext{
${ }^{1}$ Centro de Biotecnología, Universidad de Concepción, Casilla 160-C, Concepción, Chile.

${ }^{2}$ Facultad de Ciencias Forestales, Universidad de Concepción, Casilla 160-C, Concepción, Chile.

${ }^{3}$ Facultad de Ciencias Químicas, Universidad de Concepción, Casilla 160-C, Concepción, Chile.

Corresponding author: rteixeira@udec.cl
}

Received: 30.08 .2010 Accepted: 15.10.2010. 
In wood species where tension wood is present, its chemical and anatomical characteristics differ from those of opposite and normal wood. Tension wood is characterized by the presence of a gelatinous layer (G-layer) that is made up of crystalline cellulose with a low microfibrillar angle (Norberg and Meier 1966). In poplar and eucalyptus wood, fibres and vessels were significantly longer with an increase in the proportion of fibres and very thick cell walls (Baba et al. 1996, Jourez et al. 2001). Although the G-layer is the principal characteristic for determining the presence of tension wood, some studies have showed that the G-layer is absent in the tension wood of several hardwood species (Onaka 1949, Fisher and Stevenson 1981, Yoshizawa et al. 2000, Clair et al. 2006).

The chemical composition of the G-layer is characterized by high cellulose and low lignin content, which is mainly formed by syringyl units and an increased syringyl/guiacyl $(\mathrm{S} / \mathrm{G})$ ratio (Sarkanen and Hergert 1971, Baba et al. 1996, Aoyama et al. 2001, Yoshida et al. 2002). Less information has been reported on hemicellulose content and composition for both tension or opposite wood. This paper presents data on the anatomical and chemical features of tension and opposite wood by studying their presence in well-grown trees of 8-year old E. globulus, the main hardwood species growing in Chile and extensively used for short-fibre production by the local pulp and paper industry.

\section{EXPERIMENTAL}

\section{Sampling and sample preparation}

Twenty trees of 8-year old E. globulus were randomly selected and cut down from a commercial stand located in the Arauco Province (Bío Bío Region, Chile). All trees were well grown and erect without any evident trunk deformation and with the diameter at breast height (DBH) between 20 and $25 \mathrm{~cm}$. Logs of 35-40 cm were cut above $1.0 \mathrm{~m}$ height from each tree's ground line. All the logs were visually examined and five with evident tension wood formation, determined by pith asymmetry in the longitudinal axis of the log, were selected. Wood discs of $4-5 \mathrm{~cm}$ thickness were cut from each $\log$ (7-8 discs per log) and 2 discs of each log were selected; the wood was separated into tension and opposite wood. Wood from each region was also separated into sapwood and heartwood fractions, generating four samples from each disc labelled as: tension wood heartwood (TWH), tension wood sapwood (TWS), opposite wood heartwood (OWH) and opposite wood sapwood (OWS) as shown in figure 1. Heartwood and sapwood were determined visually in the E. globulus samples due to the different color presented by of each region, being heartwood darker than sapwood. The wood separated from the discs was chipped by hand, milled in a knife mill and sieved to 45/60 mesh. To determine the amount of extractives, milled wood was extracted in a Soxhlet apparatus with ethanol/ toluene for $8 \mathrm{~h}$, followed by extraction with $95 \%$ ethanol for a further $8 \mathrm{~h}$. Extractive free milled wood was used in the chemical characterization assays.

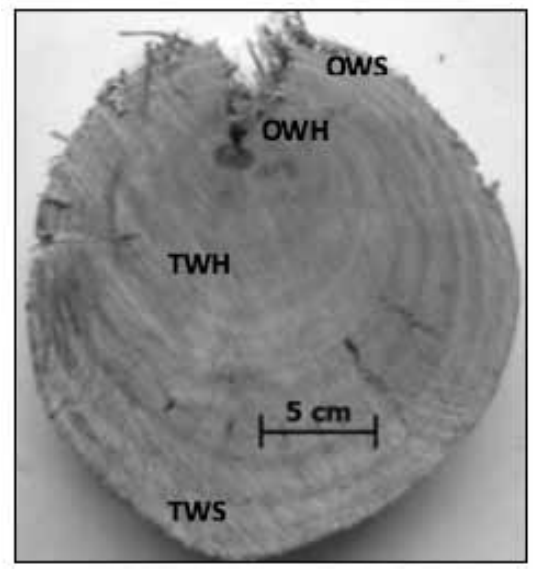

Figure 1. A disc of Eucalyptus globulus showing the wood regions sampled for anatomical and chemical analysis. TWH: tension wood heartwood, TWS: tension wood sapwood, OWH: opposite wood heartwood and OWS: opposite wood sapwood. 


\section{Anatomical measurements}

One wood disc was cut into $1 \times 1 \times 1 \mathrm{~cm}$ cubes that were softened in distilled water with a few drops of glycerine for 7 days. Microtomic slices (30 $\mu \mathrm{m}$ thickness) were cut from the cross section of each sample. The transverse sections were stained with safranin and astra blue, dehydrated in alcohol and mounted in Canadian balsam on glass slides. Microscopic images were collected using a Zeiss microscope (Primo Star) connected to a digital camera (Canon A640) attached to a personal computer to capture the images. The cell wall thickness and lumen diameter of 40 randomly selected fibres was measured with a total magnification of $100 \mathrm{X}$ by the image processing software Axiovision (Zeiss). Using 10X magnification, the number of vessel elements was determined by counting their presence in a $1 \mathrm{~mm}^{2}$ field and expressed as vessel frequency (number of vessels per square millimetre). Furthermore, twenty vessels were measured in an annual ring using 40X magnification. From the data obtained, the fibre cell wall thickness, lumen diameter, fibre diameter, vessel diameter and vessel frequency (number of vessels per $\mathrm{mm}^{2}$ ) were calculated.

\section{$\alpha$-cellulose determination}

The amount of wood $\alpha$-cellulose was quantified obtained from holocellulose preparations utilizing a procedure adapted from Yokoyama et al. (2002). Holocellulose was prepared by weighing $250 \mathrm{mg}$ of extractive free milled wood in a $50 \mathrm{~mL}$ round bottom flask and then adding $5 \mathrm{~mL}$ of deionised water, $2 \mathrm{~mL}$ of glacial acetic acid and $5 \mathrm{~mL}$ of $80 \%$ sodium chlorite. The flask was sealed with a glass cap and immersed in a water bath at $90^{\circ} \mathrm{C}$ for $1 \mathrm{~h}$. After this period, a further $2 \mathrm{~mL}$ of glacial acetic acid and $5 \mathrm{~mL}$ of $80 \%$ sodium chlorite were added to the flask and the reaction carried out for another $1 \mathrm{~h}$ at $90^{\circ} \mathrm{C}$. The reaction was stopped by immersing the flask in a water bath at $10^{\circ} \mathrm{C}$. Solids were filtered through a porous glass number 2 filter, washed with $500 \mathrm{~mL}$ of deionised water, dried at $105^{\circ} \mathrm{C}$ to constant weight and the remaining weight quantified as holocellulose. In a $25 \mathrm{~mL}$ flask, $100 \mathrm{mg}$ of holocellulose was treated with $8 \mathrm{~mL} \mathrm{17.5 \%} \mathrm{NaOH} \mathrm{(w/v)} \mathrm{for} 30 \mathrm{~min}$ at room temperature with stirring every $10 \mathrm{~min}$. Eight $\mathrm{mL}$ of distilled water was added to the solution and the reaction carried out for a further $30 \mathrm{~min}$. Solids were filtered through a porous glass number 4 filter, washed with $150 \mathrm{~mL}$ of distilled water and impregnated with $20 \mathrm{~mL}$ acetic acid $1.0 \mathrm{M}$ for 5 $\mathrm{min}$. The residue was washed with excess water and dried at $105^{\circ} \mathrm{C}$ to constant weight as $\alpha$-cellulose quantification. Analyses were performed in triplicate for each sample.

\section{Glucan and lignin}

Extractive free milled wood samples were characterized for glucan and lignin content by the procedure described by Mendonça et al. (2008). Samples (300 mg) were weighed in a test tube and $3 \mathrm{~mL}$ of $72 \% \mathrm{H}_{2} \mathrm{SO}_{4}(\mathrm{w} / \mathrm{w})$ added. Hydrolysis was performed in a water bath at $30^{\circ} \mathrm{C}$ for $1 \mathrm{~h}$ with stirring every $10 \mathrm{~min}$. Subsequently, the acid was diluted to $4 \%(\mathrm{w} / \mathrm{w})$ with $79 \mathrm{~mL}$ of distilled water; the mixture transferred to a $250-\mathrm{mL}$ Erlenmeyer flask and autoclaved for $1 \mathrm{~h}$ at $121^{\circ} \mathrm{C}$. The residual material was cooled and filtered through a porous glass number 4 filter. Solids were dried to constant weight at $105^{\circ} \mathrm{C}$ and classified as insoluble lignin. Soluble lignin was determined by measuring the solution absorbance at $205 \mathrm{~nm}$ (Dence 1992). Total lignin was calculated as the sum of insoluble and soluble lignin.

The concentration of glucose and cellobiose in the soluble fraction was determined by HPLC in a Merck Hitachi instrument with an Aminex HPX-87H column at $45^{\circ} \mathrm{C}$, eluted at $0.6 \mathrm{~mL} / \mathrm{min}$ with $5 \mathrm{mM} \mathrm{H}_{2} \mathrm{SO}_{4}$ by a refractive index detector. Glucose and cellobiose were used as external calibration standards. The factors used to convert sugar monomers to anhydromonomers were 0.90 for glucose to glucan and 0.92 for cellobiose to glucan. The sum of the anhydromonomers from glucose and cellobiose gave the amount of total glucan in wood. Further, the amount of glucan present in the hemicelluloses (from the glucomannans) determined by GC was subtracted from the total glucan determined by HPLC and the result was considered as the glucan fraction of cellulose. Analyses were performed in triplicate for each sample.

\section{Hemicelluloses quantification}

The carbohydrates present in hemicelluloses were quantified by acid methanolysis according 
to Sundberg et al. (1996). Extractive free wood meal was freeze dried prior to weighing $10 \mathrm{mg}$ into a pear shaped flask. Samples were subjected to acid methanolysis by the addition of $2 \mathrm{~mL}$ of 2.0 $\mathrm{M} \mathrm{HCl}$ in anhydrous methanol. Samples were kept in an oven at $100^{\circ} \mathrm{C}$ for $3 \mathrm{~h}$. After cooling to room temperature, $100 \mu \mathrm{L}$ of pyridine was added to neutralize the acidic solution as well as $4 \mathrm{~mL}$ of methanol (containing sorbitol at $0.1 \mathrm{mg} / \mathrm{mL}$ as an internal standard). To avoid fibres during silylation, $1 \mathrm{~mL}$ of the clear sample solution was transferred into another pear shaped flask and the solution reduced by rotary evaporation at $40^{\circ} \mathrm{C}$. Samples were dissolved in $100 \mu \mathrm{L}$ pyridine. For silylation, $150 \mu \mathrm{L}$ hexamethyldisilazane (HMDS) and $80 \mu \mathrm{L}$ trimethylchlorosilane (TMCS) were added prior to thorough shaking of the sample. After $4 \mathrm{~h}$ at room temperature, samples were analyzed by GCFID. One $\mu \mathrm{L}$ of a silylated sample was injected via a split injector $\left(260^{\circ} \mathrm{C}\right.$, split ratio $\left.1: 20\right)$ into a 30 $\mathrm{m} \times 0.25 \mathrm{~mm}$ i.d. $\mathrm{x} 0.25 \mu \mathrm{m}$ film thickness column DB5 (Agilent $\mathrm{J} \& \mathrm{~W}$ ). The column temperature program was $100^{\circ} \mathrm{C}$ to $175^{\circ} \mathrm{C}\left(4^{\circ} \mathrm{C} / \mathrm{min}\right)$ followed by $175^{\circ} \mathrm{C}$ to $290^{\circ} \mathrm{C}\left(12^{\circ} \mathrm{C} / \mathrm{min}\right)$. The detector (FID) temperature was $290^{\circ} \mathrm{C}$. Nitrogen was used as carrier gas.

Different peaks were identified by analyzing acid methanolysis products of analytical grade sugars (arabinose, xylose, galactose, glucose, mannose, rhamnose, glucuronic acid and galacturonic acid). Calibration curves and factors were determined for each sugar unit in order to calculate the concentration thereof in the wood. Analyses were performed in triplicate for each sample.

\section{Thioacidolysis}

Thioacidolysis was performed on $20 \mathrm{mg}$ of extracted milled wood in $10 \mathrm{~mL}$ of reagent according to the method published by Rolando et al. (1992). The reagent was prepared by addition of $2.5 \mathrm{~mL}$ of $\mathrm{BF}_{3}$ etherate (Aldrich) and $10 \mathrm{~mL}$ of ethanethiol EtSH (Aldrich) to a $100 \mathrm{~mL}$ flask and adjusting the final volume to $100 \mathrm{~mL}$ with dioxane. The reagent and $1 \mathrm{~mL}$ of a solution of GC internal standard (tetracosane in $\mathrm{CH}_{2} \mathrm{Cl}_{2}, 0.6 \mathrm{mg} / \mathrm{mL}$ ) were added to samples in glass tubes closed with Teflon-lined screw caps. Thioacidolysis was performed at $100^{\circ} \mathrm{C}$ (in an oil bath) for $4 \mathrm{~h}$. Cooled reaction mixtures were diluted with $30 \mathrm{~mL}$ of water and the $\mathrm{pH}$ adjusted to $3.0-4.0$ with aqueous 0.4 $\mathrm{M} \mathrm{NaHCO}_{3}$ followed by extraction with $3 \times 30 \mathrm{~mL} \mathrm{CH}_{2} \mathrm{Cl}_{2}$. The combined organic extracts were dried over $\mathrm{Na}_{2} \mathrm{SO}_{4}$, and the solvent removed under reduced pressure at $40^{\circ} \mathrm{C}$. Residues were dissolved in 1 $\mathrm{mL}$ of $\mathrm{CH}_{2} \mathrm{Cl}_{2}$ and analyzed by GC-FID after silylation in a DB-5 column (Agilent J\&W). Program temperature was the same described by $\mathrm{Lu}$ and Ralph (1997). The amount of syringyl and guaiacyl units (mmoles per $g$ of lignin) bonded by $\beta-\mathrm{O}-4$ linkages and also the frequency of $\beta-\mathrm{O}-4$ linkages in the lignin were obtained with this analysis. Analyses were performed in triplicate for each sample.

\section{Data analysis}

The normality of the anatomical and chemical data distribution, ANOVA and Tukey test were performed using the statistical software SAS System 9.0 (SAS Institute). Principal component analysis (PCA) was performed using all the anatomical and chemical data obtained in order to evaluate the spontaneous separation of samples using the software Unscrambler 9.7 (CAMO Software).

\section{RESULTS AND DISCUSSION}

\section{Anatomic characterization of the transversal sections of tension and opposite wood from $E$. globulus}

Image analysis of transverse sections cut from 5 different trees of E. globulus showed the principal differentiating characteristic was the reduced presence of lignified secondary cell walls in tension wood. Carbohydrate enriched cell walls were stained blue by astra blue, which penetrated and coloured the unlignified walls of tension wood (Figure 2B). Darker zones in fig. 2B indicated astra blue staining of G-layer cell walls. The cell walls in tension wood were also wider and thicker. 

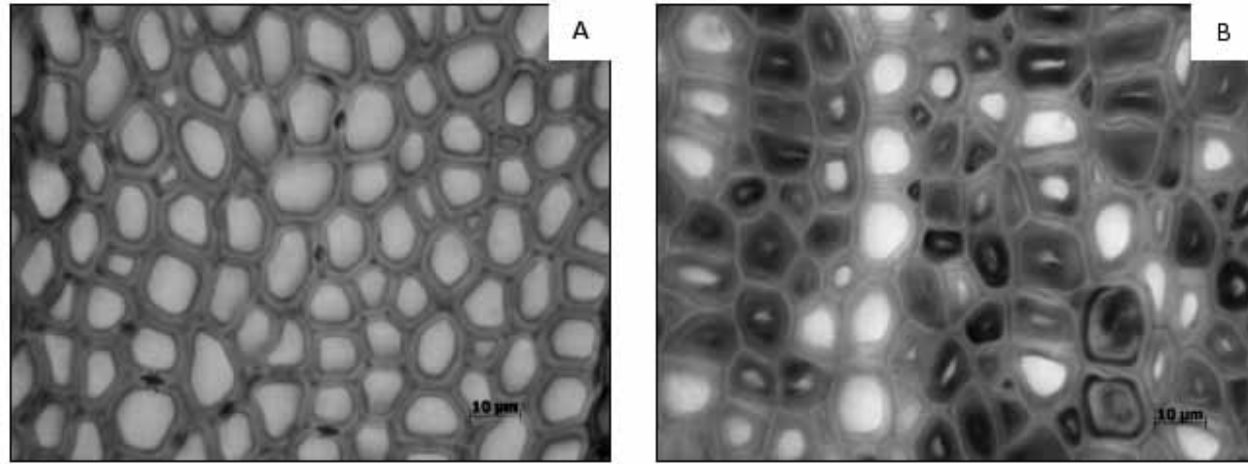

Figure 2. Transversal sections of (A) opposite and (B) tension wood of Eucalyptus globulus.

The anatomical characteristics measured in the transverse sections of tension and opposite wood of 8-year old E. globulus were the following: cell wall thickness (CWT), fibre diameter (FD), lumen diameter (LD), vessel diameter (VD) and vessel frequency (VF). The variability of each property was also measured in the heartwood and sapwood for both regions (Table 1). Statistical analysis showed a normal data distribution and a simultaneous comparison of the means for each property was tested by analysis of variance (ANOVA) and the Tukey test at $95 \%$ confidence level. The greater cell wall thickness appears as the main characteristic of tension wood $(3.2-3.5 \mu \mathrm{m})$ when compared with opposite wood $(2.8-3.0 \mu \mathrm{m})$. Vessel diameter was also slightly wider in tension wood compared to opposite wood. Similar values were found for E. globulus wood from different provenances (Miranda et al. 2001) and for E. globulus clones growing in Chile (Ramirez et al. 2009).

Table 1. Anatomical characterization of the transversal sections of tension and opposite wood of Eucalyptus globulus

\begin{tabular}{lcccccc}
\hline Component & & TWH & TWS & OWH & OWS & p-value \\
\hline $\begin{array}{l}\text { Cell wall thickness } \\
(\mu \mathrm{m})\end{array}$ & Range & $2.97-3.44$ & $3.20-4.15$ & $2.50-2.98$ & $2.85-3.10$ & \\
\hline $\bar{x}$ & $3.22^{\mathrm{a}}$ & $3.52^{\mathrm{a}}$ & $2.79^{\mathrm{b}}$ & $3.02^{\mathrm{b}}$ & $<0.0001$ \\
\hline $\begin{array}{l}\text { Fibre diameter } \\
(\mu \mathrm{m})\end{array}$ & Range & $12.77-16.74$ & $13.96-18.19$ & $11.32-15.53$ & $11.38-15.79$ & \\
\hline $\begin{array}{l}\text { Lumen diameter } \\
(\mu \mathrm{m})\end{array}$ & Range & $6.33-10.19$ & $7.56-11.09$ & $5.90-9.74$ & $5.67-9.58$ & \\
\hline $\begin{array}{l}\text { Vessel diameter } \\
(\mu \mathrm{m})\end{array}$ & Range & $98-128$ & $131-167$ & $84-111$ & $100-111$ & \\
\hline $\begin{array}{l}\text { Frequency of vessels } \\
\left(\text { number/mm }{ }^{2}\right)\end{array}$ & $\begin{array}{c}\text { Range } \\
\bar{x}\end{array}$ & $8-112^{\mathrm{b}}$ & $146^{\mathrm{a}}$ & $97^{\mathrm{c}}$ & $107^{\mathrm{bc}}$ & $<0.0001$ \\
\hline
\end{tabular}

Values with different letters within a row indicate significant differences at $\mathrm{p}<0.05$ (Tukey test).

Key - TWH: tension wood heartwood, TWS: tension wood sapwood, OWH: opposite wood heartwood and OWS: opposite wood sapwood.

Results obtained were also analyzed by PCA, which is a multivariate data analysis method suitable for describing major trends in a data set and also the relationship between samples and between variables. This procedure is applicable for comparison of samples with a large set of 
quantified variables (Naes et al. 2004). PCA shows that the first three components account for $93.4 \%$ of the variance of the data and that there is no clear separation between heartwood and sapwood. Figure 3A shows that the 2nd principal component separates many variables for tension and opposite wood without separation between heartwood and sapwood of each region. Some heartwood samples from tension wood were classified as opposite wood in the scores graph (Fig. 3A), which means that the anatomic characteristics were rather similar to the opposite wood. The most important variables separating tension from opposite wood were: cell wall thickness, vessel diameter and vessel frequency (Figure 3B).

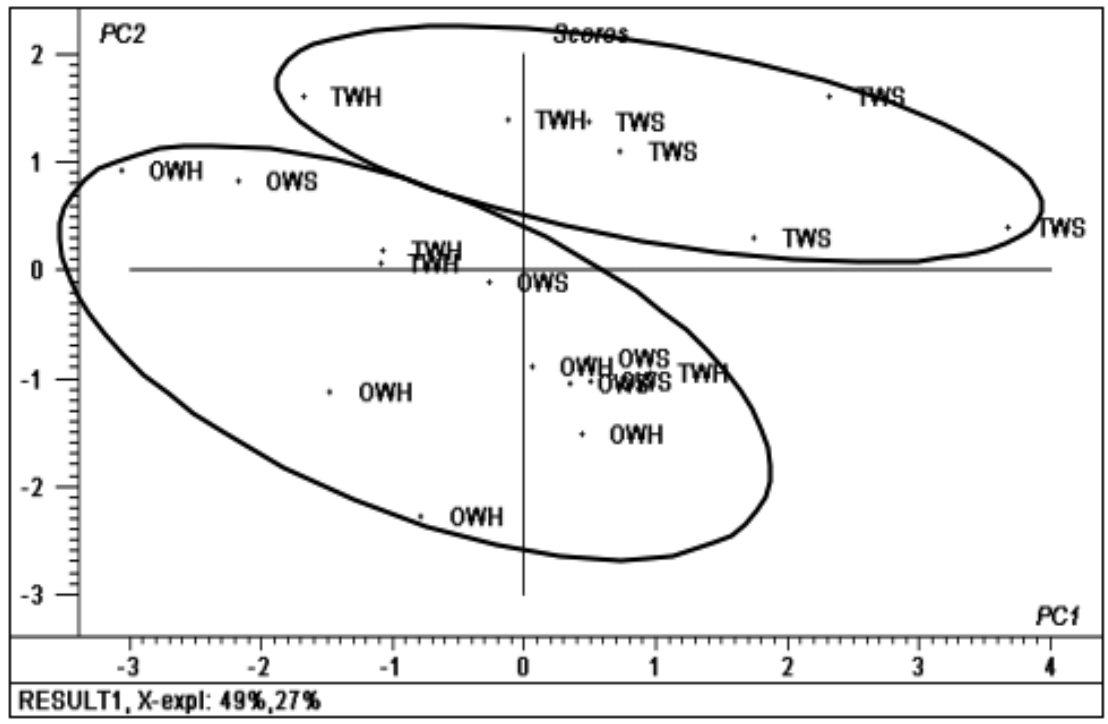

A

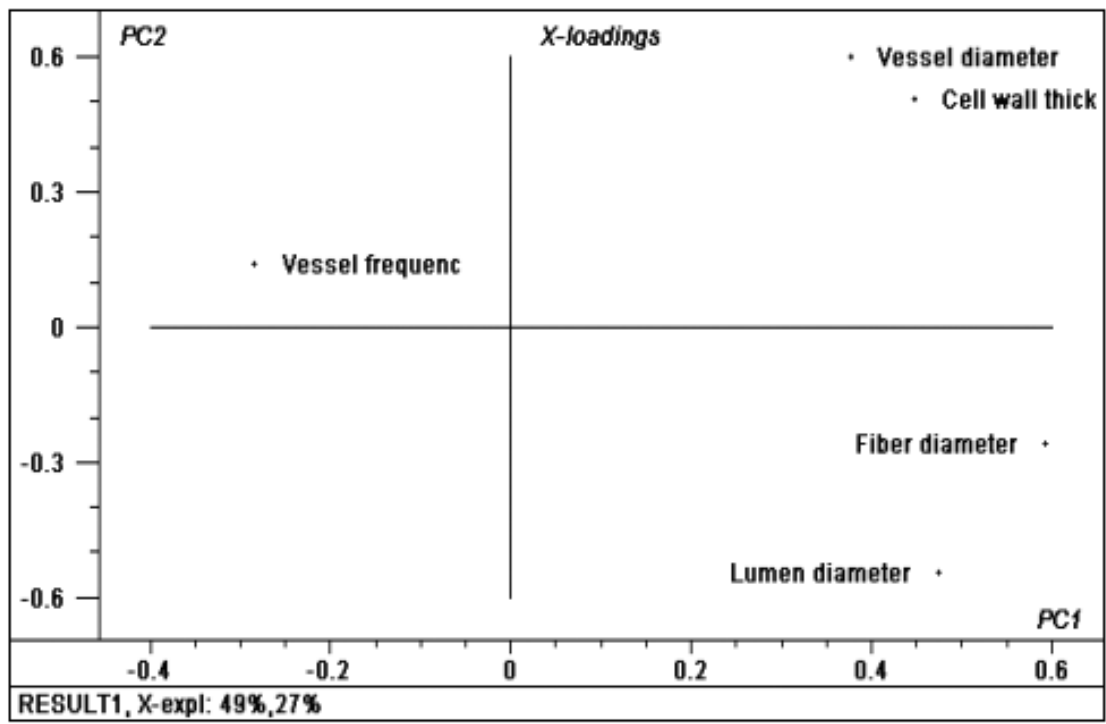

B

Figure 3. Principal component analysis of anatomical features of Eucalyptus globulus. (A) Graph of scores and (B) graph of loadings. Key - TWH: tension wood heartwood, TWS: tension wood sapwood, OWH: opposite wood heartwood and OWS: opposite wood sapwood.

\section{Chemical characterization of tension and opposite wood of $E$. globulus}

The chemical composition (quantity of extractives, glucan content in cellulose, detailed hemicellulose composition, lignin amount, amount of S and $\mathrm{G}$ units and frequency of $\beta-\mathrm{O}-4$ linkages in lignin) of heartwood and sapwood from the tension and opposite wood of E. globulus were 
characterized. Results obtained were statistically analyzed for normality and ANOVA. The Tukey test was performed to determine statistical differences among samples from the different wood regions (Table 2).

The amount of extractives was higher in heartwood for both tension and opposite wood with a lower value found in sapwood. Identified by microscopy, tension wood contained wider, thicker and poorly lignified cell walls in comparison to opposite wood. However, this visual difference is not reflected in the cellulose content as the amount of $\alpha$-cellulose and glucan in tension wood were very similar to that of opposite wood. It is postulated that the distribution of enriched carbohydrate cell walls in tension wood is non-homogeneous throughout all the regions, being located only in some regions of wood tissue, and due to its insufficient amount was not reflected in the chemical determination of cellulose in a larger wood portion. Cell wall thickness in the tension region could be highly porous and swollen when measured. The quantity of hemicelluloses was higher in tension wood (24\%) when compared to opposite wood (21-22\%), and specifically xylose was found in higher quantities in tension wood $(13 \%)$ than in opposite wood $(10 \%)$. Other carbohydrates present in hemicelluloses were similar for both tension and opposite wood. The presence of a large amount of glucose and rhamnose in the hemicelluloses of opposite sapwood could be related to the presence of more pectins, low molar mass glucan chains or starch in this type of wood.

Results also demonstrated significant differences between tension and opposite wood with respect to lignin content (22\% and $26 \%$ respectively) and that the lignin from the tension region contained $24 \%$ more syringyl units $(\sim 1700 \mu$ moles/g lignin) than that found in opposite wood $(\sim 1300$ $\mu$ moles/g lignin). No statistical difference was found for the amount of guaiacyl units, with similar values found in both tension and opposite wood (350-400 $\mu$ moles/g lignin). Similar trends were previously reported for tension wood of other species where low lignin content correlated with high syringyl units (Joseleau et al. 2004, Pilate et al. 2004, Guerra et al. 2008).

Ralph et al. (2004) and Guerra et al. (2008) previously reported a large amount of S units favours the generation of uncondensed aril-ether linkages (high amount of $\mathrm{S}$ units and low lignin content also correlated well with high frequency of $\beta$-O-4 linkages) which was also observed for the tension wood ( $46 \% \beta-\mathrm{O}-4)$ in comparison with the opposite wood (39\% $\beta-\mathrm{O}-4)$.

Sample separation of all the chemical components simultaneously and the PCA was performed to determine the most representative component of the variability. Results showed that there is no significant difference in chemical composition between heartwood and sapwood, and that the differences exhibited was due to tension and opposite wood (Figure 4A). The first principal component explained $39.1 \%$ of the variance and is the main component responsible for class separation. The amount of lignin, xylose, syringyl units and $\beta-O-4$ linkages are the variables that contributed most to the separation and chemically differentiates tension wood from opposite wood (Figure 4B). 
Table 2. Chemical characterization of tension and opposite wood of Eucalyptus globulus.

\begin{tabular}{|c|c|c|c|c|c|c|}
\hline Component & & TWH & TWS & $\mathrm{OWH}$ & OWS & p-value \\
\hline \multirow{2}{*}{ Extractives $(\%)$} & Range & $2.0-5.0$ & $1.1-4.0$ & $2.1-5.2$ & $1.2-4.4$ & \\
\hline & $\bar{x}$ & $3.1^{\mathrm{ab}}$ & $2.3^{\mathrm{b}}$ & $3.4^{\mathrm{a}}$ & $2.6^{\mathrm{ab}}$ & 0.0451 \\
\hline \multirow[b]{2}{*}{$\alpha$-cellulose $(\%)$} & Range & $41.3-46.1$ & $43.2-48.8$ & $41.5-48.7$ & $41.1-46.3$ & \\
\hline & $\bar{x}$ & $45.1^{\mathrm{ab}}$ & $46.1^{\mathrm{a}}$ & $44.7^{\mathrm{ab}}$ & $43.4^{\mathrm{b}}$ & 0.0012 \\
\hline \multirow{2}{*}{ Glucan (\%) } & Range & $44.7-51.3$ & $44.3-51.0$ & $45.8-52.9$ & $45.7-48.7$ & \\
\hline & $\bar{x}$ & $46.9^{\mathrm{a}}$ & $47.8^{\mathrm{a}}$ & $48.9^{\mathrm{a}}$ & $47.1^{\mathrm{a}}$ & 0.0491 \\
\hline \multirow{2}{*}{ Hemicellulose (\%) } & Range & $22.7-25.4$ & $22.4-25.7$ & $19.5-22-4$ & $20.6-26.5$ & \\
\hline & $\bar{x}$ & $24.1^{\mathrm{a}}$ & $24.1^{\mathrm{a}}$ & $21.1^{b}$ & $23.1^{\mathrm{a}}$ & $<0.0001$ \\
\hline \multirow{2}{*}{ Arabinose $(\%)$} & Range & $0.20-0.30$ & $0.20-0.30$ & $0.20-0.40$ & $0.20-0.40$ & \\
\hline & $\bar{x}$ & $0.27^{\mathrm{b}}$ & $0.26^{\mathrm{b}}$ & $0.30^{\mathrm{a}}$ & $0.33^{\mathrm{a}}$ & 0.0023 \\
\hline \multirow{2}{*}{ Mannose (\%) } & Range & $0.60-2.00$ & $0.80-2.10$ & $0.80-2.00$ & $0.70-1.90$ & \\
\hline & $\bar{x}$ & $1.37^{\mathrm{a}}$ & $1.28^{\mathrm{a}}$ & $1.31^{\mathrm{a}}$ & $1.11^{\mathrm{a}}$ & 0.2999 \\
\hline \multirow{2}{*}{ Xylose (\%) } & Range & $12.2-14.2$ & $12.5-15.2$ & $9.3-10.9$ & $8.3-10.8$ & \\
\hline & $\bar{x}$ & $13.3^{\mathrm{a}}$ & $13.5^{\mathrm{a}}$ & $10.2^{\mathrm{b}}$ & $9.9^{\mathrm{b}}$ & $<0.0001$ \\
\hline \multirow{2}{*}{ Glucose $(\%)$} & Range & $2.90-5.20$ & $2.40-5.30$ & $3.00-4.90$ & $5.00-7.60$ & \\
\hline & $\bar{x}$ & $4.16^{b}$ & $4.16^{\mathrm{b}}$ & $4.21^{\mathrm{b}}$ & $6.00^{\mathrm{a}}$ & $<0.0001$ \\
\hline \multirow{2}{*}{ Galactose (\%) } & Range & $0.90-1.20$ & $0.60-1.30$ & $0.60-1.50$ & $0.80-2.00$ & \\
\hline & $\bar{x}$ & $0.99^{\mathrm{b}}$ & $0.90^{\mathrm{b}}$ & $1.06^{\mathrm{b}}$ & $1.38^{\mathrm{a}}$ & 0.0003 \\
\hline \multirow{2}{*}{ Rhamnose (\%) } & Range & $0.30-0.90$ & $0.60-0.80$ & $0.50-1.00$ & $0.40-1.30$ & \\
\hline & $\bar{x}$ & $0.68^{b}$ & $0.73^{\mathrm{b}}$ & $0.79^{\mathrm{ab}}$ & $0.92^{\mathrm{a}}$ & 0.0041 \\
\hline \multirow{2}{*}{ Uronic acids (\%) } & Range & $3.0-4.1$ & $2.9-3.7$ & $2.2-3.9$ & $2.2-4.4$ & \\
\hline & $\bar{x}$ & $3.34^{\mathrm{a}}$ & $3.31^{\mathrm{a}}$ & $3.21^{\mathrm{a}}$ & $3.40^{\mathrm{a}}$ & 0.7655 \\
\hline \multirow{2}{*}{ Lignin (\%) } & Range & $20.5-22.0$ & $21.4-22.3$ & $25.3-26-5$ & $24.5-29.3$ & \\
\hline & $\bar{x}$ & $21.5^{\mathrm{b}}$ & $21.8^{\mathrm{b}}$ & $25.7^{\mathrm{a}}$ & $26.1^{\mathrm{a}}$ & $<0.0001$ \\
\hline \multirow{2}{*}{$\begin{array}{l}\text { G-units } \\
(\mu \mathrm{mol} / \mathrm{g} \text { lignin })\end{array}$} & Range & $316-446$ & $348-500$ & $268-495$ & $253-473$ & \\
\hline & $\bar{x}$ & $400^{\mathrm{a}}$ & $401^{\mathrm{a}}$ & $351^{a}$ & $332^{\mathrm{a}}$ & 0.0031 \\
\hline \multirow{2}{*}{$\begin{array}{l}\text { S-units } \\
(\mu \mathrm{mol} / \mathrm{g} \text { lignin })\end{array}$} & Range & $1630-1874$ & 1609-1904 & 1171-1395 & 1121-1494 & \\
\hline & $\bar{x}$ & $1732^{\mathrm{a}}$ & $1707^{\mathrm{a}}$ & $1261^{\mathrm{b}}$ & $1318^{\mathrm{b}}$ & $<0.0001$ \\
\hline \multirow{2}{*}{$\beta-O-4$ linkages $(\%)$} & Range & $42.1-49.9$ & $41.7-51.7$ & $35.9-41.2$ & $35.0-42.3$ & \\
\hline & $\bar{x}$ & $45.9^{\mathrm{a}}$ & $43.9^{\mathrm{a}}$ & $39.1^{\mathrm{b}}$ & $38.5^{\mathrm{b}}$ & $<0.0001$ \\
\hline
\end{tabular}

Values with a different letter within a row indicate significant differences at $\mathrm{p}<0.05$ (Tukey test). Key - TWH: tension wood heartwood, TWS: tension wood sapwood, OWH: opposite wood heartwood and OWS: opposite wood sapwood. 


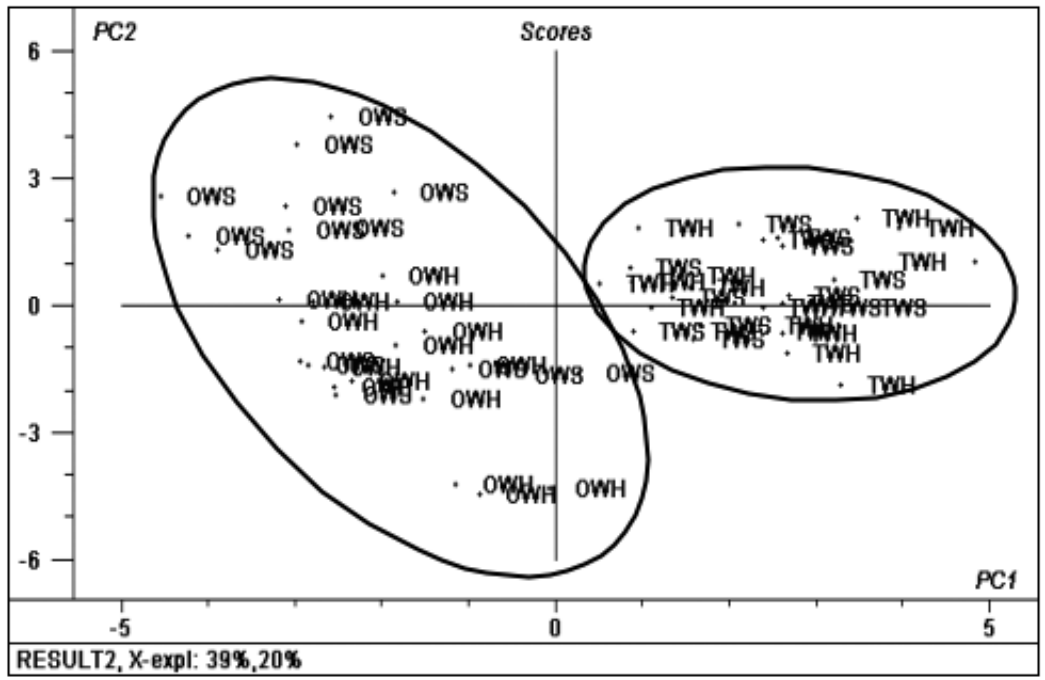

A

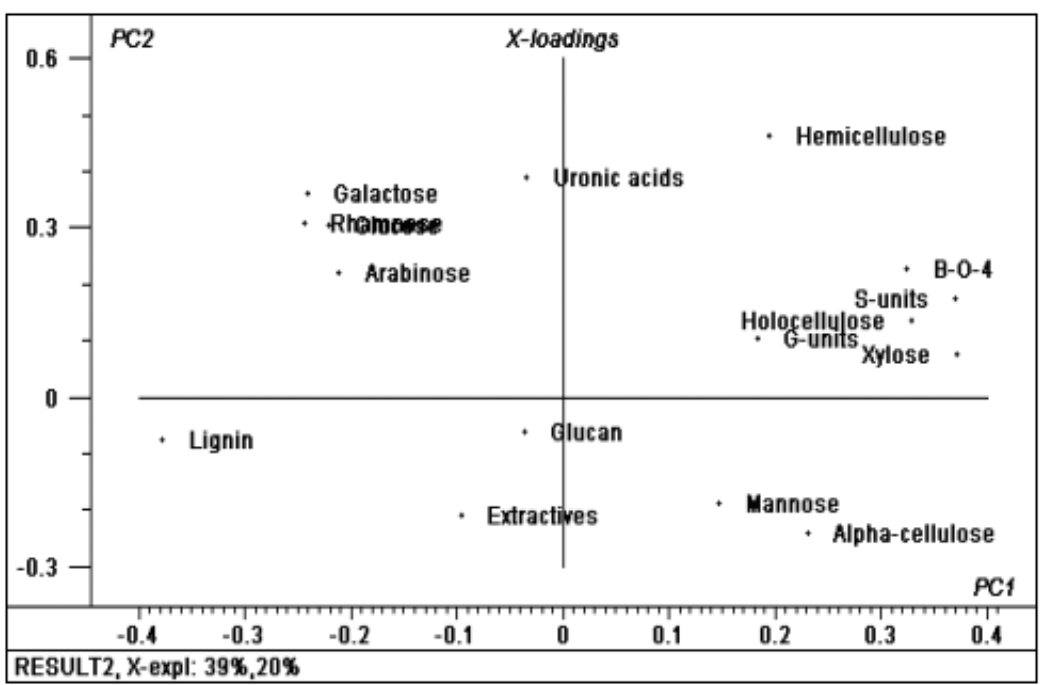

Figure 4. Principal component analysis of chemical features of Eucalyptus globulus. (A) Graph of scores and (B) graph of loadings. Key - TWH: tension wood heartwood, TWS: tension wood sapwood, OWH: opposite wood heartwood and OWS: opposite wood sapwood.

\section{CONCLUSIONS}

The commercial use of a given forest species depends upon several genotype characteristics, such as growth rate and tree form; once in the field, plant development depends upon the site and environmental conditions that also affect wood properties and quality. One important characteristic to consider is the presence of reaction wood, and specifically in the case of the hardwoods, is the amount of tension wood, which could affect the processes of wood conversion. To better estimate this effect, the main characteristics of this type of wood need to be identified. Analysis of tension and opposite wood in well grown E. globulus trees indicated significant differences in both anatomical and chemical characteristics. For tension wood from the E. globulus trees analyzed, the most evident features were: thicker cell walls, high xylose content, low lignin content, large amount of syringyl units and high abundance of $\beta-\mathrm{O}-4$ linkages. 


\section{ACKNOWLEDGEMENTS}

Financial support from "Fondo Nacional de Desarrollo Científico y Tecnológico" (FONDECYT, grant 1080105) is gratefully acknowledged.

\section{REFERENCES}

Aoyama, W.; Matsumura, A.; Tsutsumi, Y.; Nishida, T. 2001. Lignification and peroxidase in tension wood of Eucalyptus viminalis seedlings. J. Wood Sci. 47:419-424.

Baba, K.; Ona, T.; Takabe, K.; Itoh, T.; Ito, K. 1996. Chemical and anatomical characterization of the tension wood of Eucalyptus camaldulensis L. Mokuzai Gakkaishi 42: 795-798.

Bamber, R.K. 2001. A general theory for the origin of growth stresses in reaction wood: How trees stay upright. IAWA J. 22:205-212.

Clair, B.; Ruelle, J.; Beauchêne, J.; Prévost, M.F.; Fournier, M. 2006. Tension wood and opposite wood in 21 tropical rain forest species 1. Occurrence and efficiency of the G-layer. IAWA J. 27:329338.

Dence, C.W. 1992. The determination of lignin. In: Lin SY, Dence CW (eds) Methods in Lignin Chemistry. Springer, Berlin, pp 33-61.

Fisher, J.B.; Stevenson, J.W. 1981. Occurrence of reaction wood in branches of dicotyledons and its role in tree architecture. Bot. Gaz. 142:82-95.

Guerra, A.; Elissetche, J.; Norambuena, M.; Freer, J.; Valenzuela, J.; Rodríguez, J.; Balocchi, C. 2008. Influence of lignin structural on Eucalyptus globulus kraft pulping. Ind. Eng. Chem. Res. 47:8542-8549.

Joseleau, J.P.; Imai, K.; Kuroda, K.; Ruel, K. 2004. Detection and in situ characterization of lignin in the G-layer of tension wood fibres of Populus deltoides. Planta 219:338-345.

Jourez, B.; Riboux, A.; Leclercq, A. 2001. Anatomical characteristics of tension wood and opposite wood in young inclined stems of poplar (Populus euramericana). IAWA J. 22:133-157.

Lu, F.; Ralph, J. 1997. DFRC method for lignin analysis. 1. New method for b-Arly Ether cleavage: Lignin model studies. J. Agric. Food Chem. 45:4655-4660.

Mendonça, R.T.; Jara, J.; González, V.; Elissetche, J.; Freer, J. 2008. Evaluation of the white-rot fungi Ganoderma australe and Ceriporipsis subvermispora in biotechnological applications. J. Ind. Microbiol. Biotechnol. 35:1323-1330.

Miranda, I.; Almeida, M.H.; Pereira, H. 2001. Variation of fiber biometry in different provanences of Eucalyptus globulus Labill. Appita J. 54:272-280.

Naes, T.; Isaksson, T.; Fearn, T.; Davies, T. 2004. A user-friendly guide to multivariate calibration and classification. John Wiley \& Sons, Chichester.

Norberg, P.H.; Meier, H. 1966. Physical and chemical properties of the gelatinous layer in tension wood fibres of Aspen (Populus tremula L). Holzforschung 20:174-178. 
Pilate, G.; Chabbert, B.; Cathala, B.; Yoshinaga, A.; Leplé, J-C.; Laurans, F.; Lapierre, C.; Ruel, K. 2004. Lignification and tension wood. C. R. Biologies 327:889-901.

Ralph, J.; Lundquist, K.; Brunow, G.; Lu, F.; Kim, H.; Schatz, P.F.; Marita, J.M.; Hatfield, R.D.; Ralph, S.; Holst, J.; Boerjan, W. 2004. Lignins: Natural polymers from oxidative coupling of 4-hydroxyphenyl-propanoids. Phytochemistry Rev. 3:29-60.

Ramírez, M.; Rodríguez, J.; Balocchi, C.; Peredo, M.; Elissetche, J.P.; Mendonça, R.T.; Valenzuela, S. 2009. Chemical composition and wood anatomy of Eucalyptus globulus clones, its variations and relationships with pulpability and handsheet properties. J. Wood Chem. Technol. 29: 43-58.

Rolando, C.; Monties, B.; Lapierre, C. 1992. Thioacidolysis. In: Lin SY, Dence CW (eds) Methods in Lignin Chemistry. Springer, Berlin, pp 334-350.

Sarkanen, K.V.; Hergert, H.L. 1971. Classification and distribution. In: Sarkanen KV, Ludwig CH (eds.) Lignins: occurrence, formation, structure and reactions. John Wiley \& Sons, New York, pp. 43-89.

Sundberg, A.; Sundberg, K.; Lillandi, C.; Holmbom, B. 1996. Determination of hemicelluloses and pectins in wood and pulp by acid methanolysis and gas chromatography. Nordic Pulp Paper Res. J. 11: 216-226.

Wahyudi, I.; Okuyama, T.; Hadi, Y.S.; Yamamoto, H.; Yoshida, M.; Watanabe, H. 2000. Relationship between growth rate and growth stresses in Paraserianthes falcataria grown in Indonesia. J. Trop. For. Prod. 6: 95-105.

Wahyudi, I.; Okuyama, T.; Hadi, Y.S.; Yoshida, M.; Watanabe, H. 1999. Growth stresses and strains in Acacia mangium. For. Prod. J. 49: 77-81.

Washusen, R. 2002. Tension wood occurrence in Eucalyptus globulus Labill. 2. Spatial distribution of tension wood in 10 trees and its relationship with tree form. Aust. For. 65: 127-134.

Washusen, R.; Ilic, J. 2001. Relationship between transverse shrinkage and tension wood from three provenances of Eucalyptus globulus Labill. Holz Roh Werks 59:85-93.

Yokoyama, T.; Kadla, J.F.; Chang, H-M. 2002. Microanalytical method for the characterization of fiber components and morphology of woody plants. J. Agric. Food Chem. 50:1040-1044.

Yoshida, M.; Ohta, H.; Okuyama, T. 2002. Tensile growth stress, lignin distribution in the cell walls of black locust (Robinia pseudoacacia). J. Wood Sci. 48: 99-105.

Yoshizawa, N.; Inami, A.; Miyake, S.; Ishiguri, F.; Yokota, S. 2000. Anatomy and lignin distribution of reaction wood in two Magnolia species. Wood Sci. Technol. 34:183-196. 
